\title{
Centralized Heating System with Heat Pumps
}

\author{
Oleg Stepanov ${ }^{1, *}$ and Polina Tretyakova ${ }^{1}$ \\ ${ }^{1}$ Industrial University of Tyumen, 625001 Volodarskogo str. 38 Tyumen, Russia
}

\begin{abstract}
The authors introduce the centralized heat supply system of remote consumers which is based on the heat pump systems using secondary energy resources of a thermal power plant as a source of lowgrade heat. To assess the effectiveness of the proposed system, the indexes of thermal efficiency are given. The authors describe a mathematical model of determining the dependence of the discounted net profit of consumers' remoteness, the pipe diameter, and the thermal input of the consumer groups located in the city of Tyumen as a result of the introduction of heat pumps in the centralized heating based on the combined heat and power plant.
\end{abstract}

\section{Introduction}

In fact, the most important task is to select main energy sources while designing and constructing energy-efficient heating systems in residential and public buildings, because the main purpose of the Federal Law of 23.11.2009 № 261-FL [1] is to reduce the use of resources consumed in the heating needs while maintaining the consequent benefits from their use.

When considered thermodynamically, the combined production of electricity and heat at the combined heat and power plant (CHPP) is much more efficient than separate production of electricity at condensing thermal power plants and heat boilers [2]. However, the use of centralized heat supply systems has disadvantages:

1) a high level of heat energy losses in heat systems (across northern latitudes);

2) an increase in the cost of fuel and energy resources;

3 ) depreciation of heat systems and equipment, and thus a high level of thermal networks operating costs;

4) violation of hydraulic control of heat systems which leads to underheating and overheating [3].

These unresolved technical and economic problems have a negative impact on the quality and energy efficiency of centralized heat supply in Russia.

The Decree of the Government of the Russian Federation of November 13, 2009 № 1715-p approved the Energy Strategy of Russia up to 2030. According to it, the aim of the energy policy of Russia is to establish the most efficient use of natural energy resources and ensure ecological safety of Russia's energy sector. A significant role is assigned to the development of renewable energy sources [4]. Their usage will save fossil fuels; will balance energy demand due to the needs of consumers located either away from centralized

* Corresponding author: kpt@,tgasu.ru 
heat systems or close to them, and will reduce the environmental pressure on the part of energy enterprises.

The proposed technical solution is aimed to increase the efficiency of the centralized heat supply of remote heat consumers using heat pump systems utilizing low-grade thermal energy of thermal power plants (TPP).
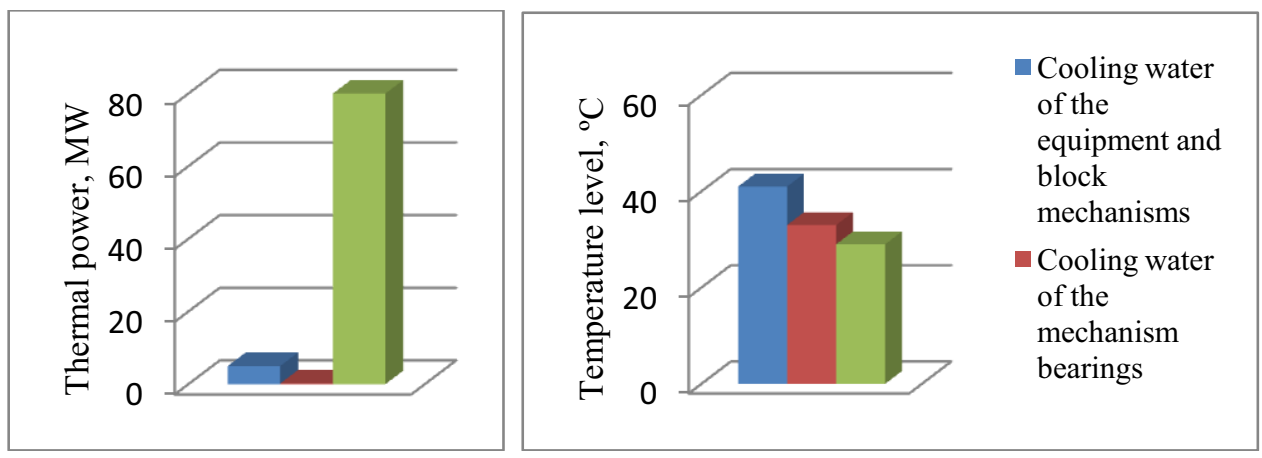

Fig. 1. Thermal power and temperature of renewable energy resources at the combined cycle cogeneration plant (CCCP).

Figure 1 shows thermal power and temperature level of thermal secondary energy resources of a combined-cycle plant (CCP), as exemplified by CCP-110 [5]. The cooling water of the equipment and block mechanisms is of the highest temperature. Its usage as a source of low-grade heat increases the transformation rate of a heat pump system. But water consumption is low and in this case it is more efficient to use it for hot water supply or heating water for cold water supply (CWS).

Taking into account the consumption of heating areas of the city, it is possible to use cooling water thermal power of a vacuum-condensation system [6].

The heat pumps improve the existing technologies of electric and thermal energy and reduce the pressure on the environment by reducing emissions of the pollutants produced due to combustion of natural gas [7]. In addition, the share of alternative energy sources in the supply-demand balance will increase.

\section{Subjects and methods}

Currently, there are a large number of works devoted to the modernization of the existing system using heat pump systems aimed to improve energy efficiency and the development of combined systems, which combine structural elements of centralized and decentralized heat supply systems. Further, we will consider three main categories of heat pumps application:

- as a peak source $[8,9]$;

- to use reversed heating system water as low-grade heat $[10,11]$;

- to reduce a temperature chart of a heat supply system $[12,13]$.

The integration of heat pump technology in the combined production of heat and electricity increases the production of electricity by reducing losses in heating mains while reducing the temperature of the heat-transfer fluid in the lines, and increases thermal transfer capacity at the same flow rate. More efficient use of fuel energy reduces $\mathrm{CO} 2$ emissions [14]. The transition to a low-temperature schedule of heating mains increases the service life, reduces the breakdown rate and material costs by using cheaper heat insulating materials. In the long run, it is quite realistic to introduce different heat tariffs from CHPP - depending on the capacity [15]. 
To provide remote consumers, we suggest using the centralized heat supply system. In this system, CHPP transfers a low-grade heat-transfer fluid (cooling water thermal power of a vacuum-condensation system) to a central heating station (CHS) which is equipped with heat pumps for heating and hot water supply (HWS).

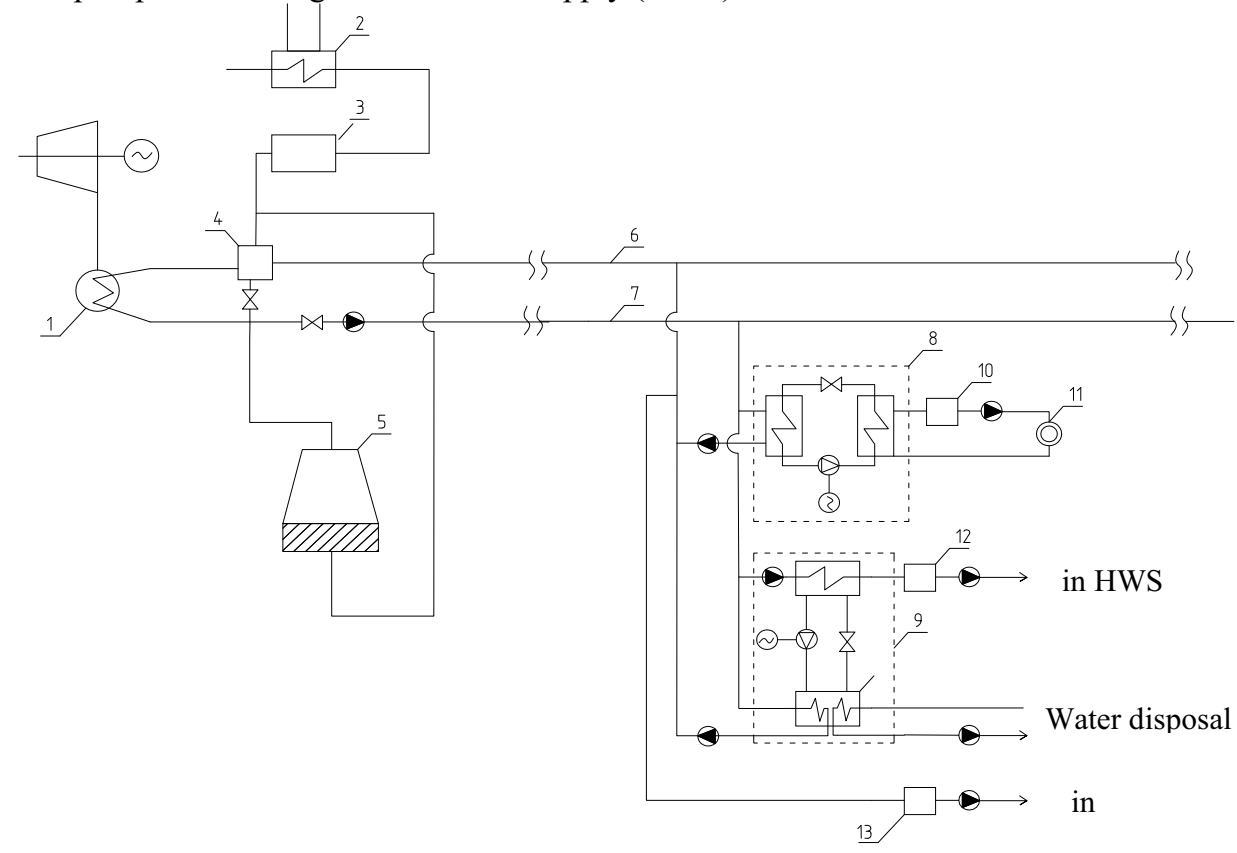

Fig. 2. The heating system using a heat pump: the steam-turbine condenser of CHPP 1, the heat exchanger of cooling system of units and mechanisms 2 , the water purification plant 3 , the water storage tank 4, the cooling tower 5 , straight 6 and 7 reverse system water pipes and remote heat points and heat consumers 11. Each remote heat point includes a heat pump plant of a heating system, a heat pump of hot water system, a hot water storage tank 12 , a cold water storage tank 13 , a hot water storage tank of the heating system 10 [17].

One part of heat-transfer fluid giving up heat to a heat pump system, returns to CHPP through the return pipeline of heating-system water, and another part is taken by hot water system of consumers. Domestic sewage water is directed to the evaporator inlet of the heat pump of the hot water supply system, and heating water is directed to the evaporator only in case of absence or shortage of domestic sewage heat [16].

Figure 2 shows one of the possible centralized heating systems implementing the proposed method.

Source water is supplied through a pipeline by the heat exchanger 2 in the water purification plant 3 and added to the water storage tank 4 , which also receives water from the reverse system water pipes 6 . The heating water from the water storage tank 4 is heated in the steam-turbine condenser 1 and is transported by a pipeline network 3 to remote heat points equipped with compression heat pumps and the unclaimed water is cooled in the cooling tower 5 .

In the heat pump of the heating system, the water low-grade heat of the heating water pipe is transported to the working fluid of the evaporator heat pump. The cooled water is fed into the reverse pipe. The condensation of the working fluid of the heat pump in the heating system is carried out by return water from the heat consumer 11 .

In the heat pump of the hot water system, the domestic sewage heat and / or straight reverse system water pipe are transferred to the working fluid of the heat pump in the 
evaporator. As a result, the cooling water is fed into the reverse system water pipe and waste water goes down the drain. The condensation of the working fluid of the heat pump of the hot water system is carried out by the water supplied from the straight system water pipe 3. The water in the condenser is heated up to the temperature of hot water system and then it is directed to the hot water storage tank 12.

If necessary, the cold water from the storage tank 13 is collected from the reverse system water pipe, and then it is directed by a pump to the consumers.

The evaluation of the proposed solution of heat pump usage is based on the electric / heat output ratio $\mathrm{E}[\mathrm{MWt} / \mathrm{Gcal}][\mathrm{MWtEE} / \mathrm{MWtHE}]$ and the coefficient of fuel heat utilization (CFHU) [18, 19].

\section{Results}

Heat pumps produce the load required by the consumers. In addition, pipe losses are reducing and as a consequence, steam flow is decreasing which increases electricity generation. But a part of the load is spent on the compressor drives of heat pump systems.

The electric / heat output ratio can be represented as a ratio of underproduced electrical energy to generated thermal energy [MWt / Gcal] [MWtEE / MWtHE].

$$
E=\frac{\Delta N}{Q_{\text {determ }}}
$$
MWt

Where: $\Delta N$ - electricity additionally produced by the work of condensing cycle CHPP,

$Q_{\text {determ }}$ - thermal energy of network heaters, MWt

The heat generation / electric output ratio can be considered as a reverse value of electric / heat output ratio (equivalent of the conversion ratio of heat pumps):

$$
\varphi_{\text {hppchs }}=\frac{1}{E}=\frac{h_{\text {exir }}^{\prime \prime}-h_{\text {exir }}^{\prime}}{\eta_{o i} \eta_{m} \eta_{e}\left(h_{\text {exir }}^{\prime \prime}-h_{\text {condenser }}\right)}
$$

Where: $h^{\prime \prime}$ exir,$h_{\text {exir }}^{\prime}$ - enthalpy of steam input and enthalpy of water leaving network heater, $\mathrm{kj} / \mathrm{kg}{ }^{\circ} \mathrm{C}$;

$\eta_{o i}$ - relative internal turbine's efficiency;

$\eta_{\mathrm{M}} \eta_{E}$ - electromechanical turbine's efficiency;

$\mathrm{h}_{\text {condenser }}$ - enthalpy of steam in the condenser.

The electric power is extra expensed due to the use of heat pumps (HP) in the CHS to the compressor drive:

$$
N_{\text {condenser }}=\frac{\sum Q_{h p p c h s}}{\varphi_{h p p c h s}}
$$

Where: $\varphi_{\text {hpp chs }}$ - coefficient of heat pump performance of CHS;

$\sum \varphi H P P C H S$ - amount of thermal energy generated by the heat pump, MWt.

The total thermal capacity of HP consists of the amount of heat coming from the source of low-grade heat and the compressor's electric power. Since the heat pump uses the rejected heat, energy saving will be: 


$$
\Delta N_{\text {transportlosser }}=\frac{\sum Q_{h p p c h s}}{\varphi_{\text {chpp }}}
$$

Electric power generated optionally due to reducing transport losses.

$$
\Delta N_{\text {pipe }}=\frac{Q_{\text {pipe }}-Q_{\text {pipe }}}{\varphi_{\text {chpp }}}
$$

Where: $Q_{\text {pipe }}-Q_{\text {pipe }}{ }^{\prime}-$ loss of thermal energy while transporting the heat transfer fluid from the CHPP to the CHS without heat pumps and with them in the CHS.

Changes in electricity generation by means of the heat pump plant (HPP) in CHS:

$$
\Delta N_{h p p c h s}=\Delta N_{\text {transportlosser }}-N_{\text {condenser }}=\frac{\sum Q_{h p p c h s}}{\varphi_{\text {chpp }}}-\frac{\sum Q_{h p p c h s}}{\varphi_{h p p c h s}}=\sum Q_{h p p c h s}\left(\frac{1}{\varphi_{c h p p}}-\frac{1}{\varphi_{h p p c h s}}\right)
$$

Changing of HPP electrical power:

$$
\begin{aligned}
& \Delta N_{h p p+h p p}=\Delta N_{h p p c h s}+\Delta N_{p i p e}=\sum Q_{h p p c h s}\left(\frac{1}{\varphi_{c h p p}}-\frac{1}{\varphi_{h p p c h s}}\right)+\frac{Q_{p i p e}-Q_{p i p e}}{\varphi_{c h p p}} \\
& =\frac{\Delta Q_{p i p e}+\sum Q_{h p p c h s}}{\varphi_{c h p p}}-\frac{\sum Q_{h p p c h s}}{\varphi_{h p p c h s}}
\end{aligned}
$$

Then the change in power generation at thermal consumption for HP - CHPP with HP will be:

$$
\begin{aligned}
& \Delta R=E_{1}-E=\frac{\Delta N+\Delta N_{\text {chp } p+h p p}}{Q_{\text {determ }}}-\frac{\Delta N}{Q_{\text {determ }}}=\frac{\Delta N_{\text {chpp } h p p}}{Q_{\text {determ }}}= \\
& =\frac{1}{Q_{\text {determ }}}\left(\frac{\Delta Q_{\text {pipe }}+\sum Q_{h p p c h s}}{\varphi_{\text {chp } p}}-\frac{\sum Q_{h p p c h s}}{\varphi_{\text {hp chs }}}\right)
\end{aligned}
$$

Changing of the coefficient of fuel heat utilization (CFHU) - the proportion of the fuel heat, useful electricity and heat gain. In other words, the ratio

$$
C F H U=\frac{W_{\text {sustem }}^{\Sigma}+Q_{\text {sustem }}^{\Sigma}}{B_{\text {district }}}=\eta_{\text {district }}^{e}+\eta_{\text {district }}^{t}
$$

where $B_{\text {district }}=B_{e}^{\Sigma}+B_{t}^{\Sigma}-$ fuel consumption

$B_{e}^{\Sigma}$ - fuel consumption for the production and supply of electricity;

$B_{t}^{\Sigma}$ - the same for heat;

$W_{\text {sustem }}^{\Sigma}, Q_{\text {sustem }}^{\Sigma}$ - electricity and heat consumption of the district

Changing of the coefficient of fuel heat utilization - additionally generated electricity to heat of the fuel burned in combustion chambers of gas turbines $\left.\left(Q_{t}\right) \mathrm{Q}_{\mathrm{Tот}}\right)$ : 


$$
\Delta C F H U=\frac{\Delta N}{Q_{t}}
$$

If HPP uses rejected heat in CHS, then

$$
\Delta C F H U=\frac{1}{Q_{t}}\left(\sum Q_{h p p c h s}\left(\frac{1}{\varphi_{c h p p}}-\frac{1}{\varphi_{h p p c h s}}\right)+\frac{Q_{\text {pipe }}-Q_{\text {pipe }}}{\varphi_{\text {chpp }}}\right)
$$

When the use of heating systems with heat pumps is effective from the thermodynamic point of view, the minimum value of heat transformation ratio can be calculated according to the conditions: electricity underproduced as a result of heat energy in a standard schema must be greater than the share of electricity underproduced in the schema with HPP.

$$
\begin{aligned}
& \left.\frac{1}{\varphi_{\text {chpp }}}\right\rangle \frac{1}{\varphi_{\text {hpp chs }}}-\frac{\Delta \eta_{\text {pipe }}}{\varphi_{c h p p}} \\
& \left.\varphi_{\text {hpp chs }}\right\rangle \frac{\varphi_{\text {chpp }}}{1+\Delta \eta_{\text {pipe }}}
\end{aligned}
$$

where: $\frac{1}{\varphi_{\text {hpp chs }}}-$ the share of electricity spent on the compressor drive;

$$
\frac{\Delta \eta_{\text {pipe }}}{\varphi_{\text {chpp }}}-\text { the share of electricity saved by reducing pipe losses. }
$$

The analysis of the presented above equations shows that the system is effective only at high conversion effectiveness of HP (use of low-temperature heating systems) and high pipe losses in the existing system.

We want to evaluate the effectiveness of the proposed heating system for a conventional settlement with the building area of $700 \mathrm{~km} 2$ and consumed heat input of $5.6 \mathrm{mln}$ Gcal. When CHPP is located as close as possible to the center of the settlement, the most remote consumer is located in $15 \mathrm{~km}$ from the source of thermal energy. The total heat loss is 1.68 Gcal/year. When $\varphi_{\text {hp } p h s}=3.9$ and $\varphi_{\text {chpp }}=4.73 \quad \varphi_{H P P C H S}=3.9$ and $\varphi_{C H P P}=$ 4.73we get an efficiency limit of HPP across $7 \mathrm{~km}$ (Fig. 3).

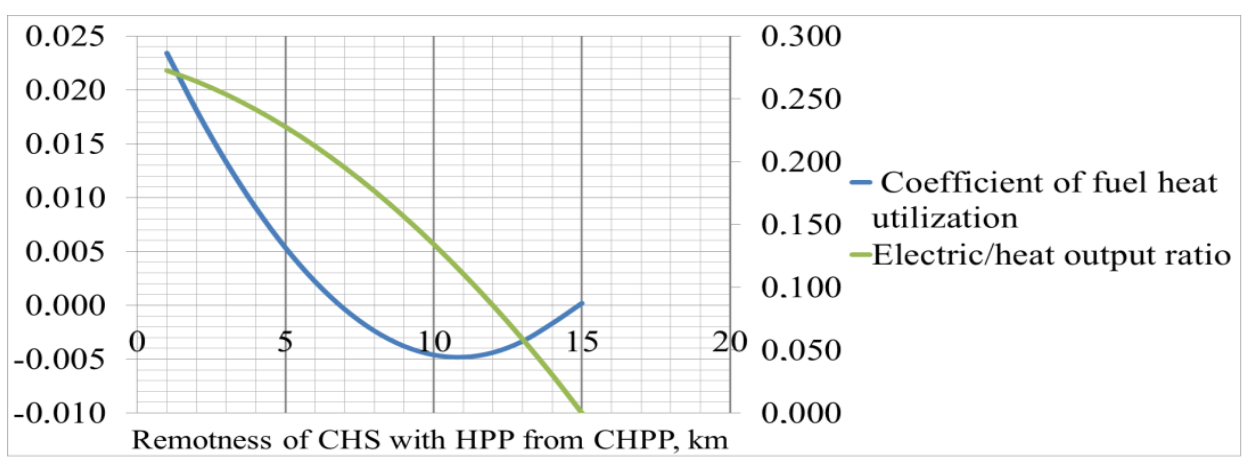

Fig. 3. Dependence of the coefficient of fuel heat utilization and electric/heat output ratio on the consumer remoteness from CHPP. 


\section{TPACEE-2016}

Technical and economic indicators of the heat supply systems with heat pumps depend on the consumption and electricity cost, capital costs for the systems. In its turn, the electricity cost is reducing while the speed reduction of heat-transfer fluid in the main pipeline. But the capital expenditures on the heat supply system increase, since the pipeline diameter increases:

$$
N P V=f\left(l_{\text {pipe }}, d_{\text {pipe }}, q_{\text {consumer }}\right)
$$

To determine the dependence of net discounted profits on the pipeline length (remoteness of customers) $\left(l_{\text {pipe }}\right)$, pipeline diameter $\left(d_{\text {pipe }}\right)$ and consumers' heat input ( $\left.q_{\text {consumer }}\right)$, we built a mathematical model based on the method of orthogonal central compositional planning $[20,21]$ applicable for the climatic parameters of Tyumen, and calculated net discounted profits on the basis of the model. As a result, we have the dependence $N P V=f\left(l_{\text {pipe }}, d_{\text {pipe }}, q_{\text {consumer }}\right)$ in the form of an equation:

$$
\begin{aligned}
& y=-57953586+477314 \cdot d-1080373 \cdot l+1482485 \cdot \mathrm{q}+9829 \cdot \mathrm{dl}+ \\
& +31028 \cdot \mathrm{dq}-410045 \cdot \mathrm{lq}-1303 \cdot \mathrm{d}^{2}-118871 \cdot \mathrm{l}^{2}-196220 \cdot \mathrm{q}^{2}
\end{aligned}
$$

These results allow us to determine the optimal size of the diameter, the remoteness of consumers and their input. For example, the optimum diameter of the pipeline from the CHPP is $380 \mathrm{~mm}$ if the input of consumers is $5 \mathrm{Gcal} / \mathrm{h}$ and the remoteness from the CHPP is $7 \mathrm{~km}$, while the NPV is 38.091 thousand rubles when replacing an existing source of heat boiler (Fig. 4).

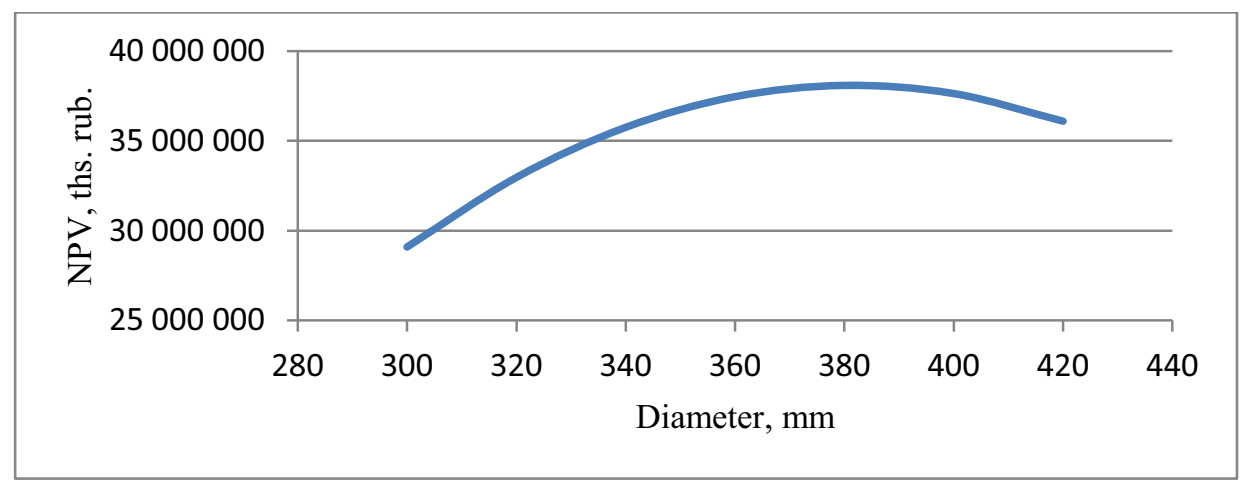

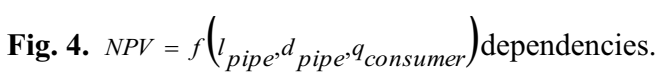

We can determine the optimum temperature for the calculation of the heating system of a developing area with $380 \mathrm{~mm}$ pipeline diameter (Fig. 5, Fig. 6). 


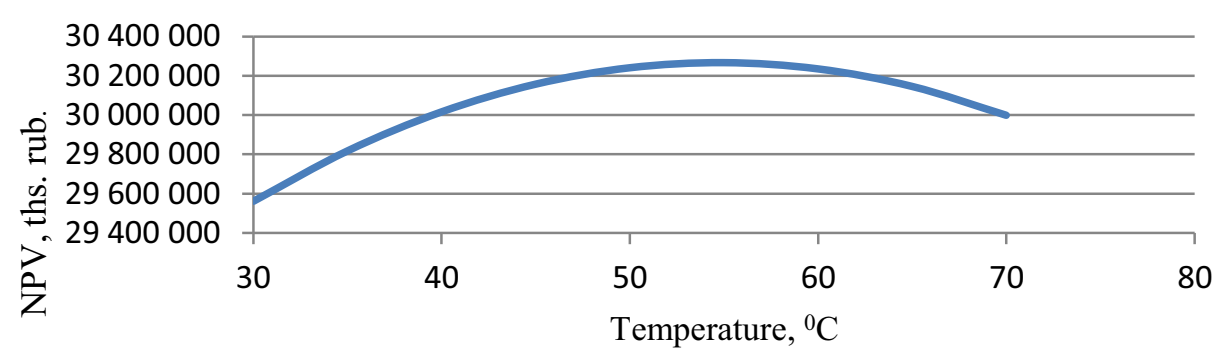

Fig. 5. The optimum temperature in the supply pipeline.

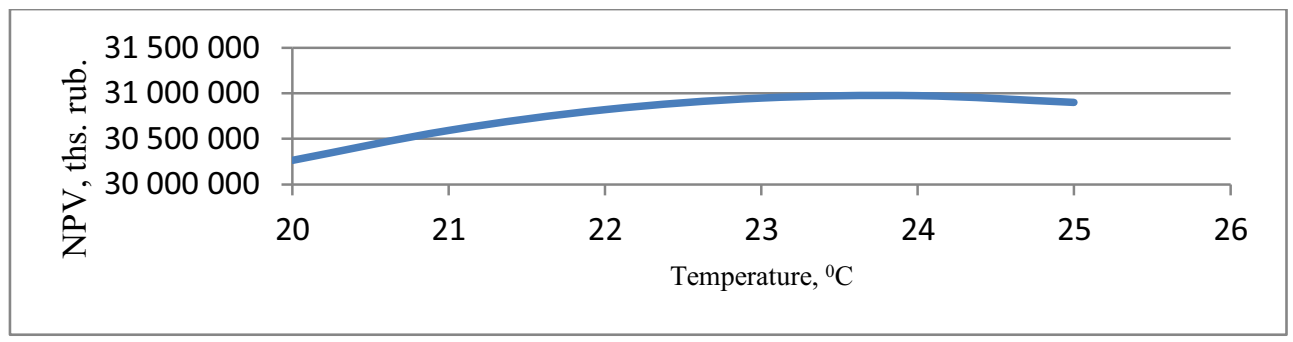

Fig. 6. The optimum temperature in the return pipeline.

\section{Summary}

We have developed a heat supply system for remote heat stations of a low-grade heattransfer fluid from CHPP (it is obtained after heat recovery from steam-turbine condenser and cooling water of the equipment and mechanisms of the electrical power unit). Each heat station is equipped with vapor compression heat pumps of the heat supply system and hot water supply. A part of heat-transfer fluid returns to CHPP through the return pipeline of heating-system water, and another one is taken by the hot water system of consumers.

We have proposed heat efficiency indicators of $\mathrm{CCCP}$ - heating main- $\mathrm{CHS}$ to assess the effectiveness of the proposed heat supply system: changing of the coefficient of fuel heat utilization and changing of the electric/heat output ratio.

We have built a mathematical model to determine the dependence of net discounted profits as a result of the introduction of heat pumps in the centralized heat supply system based at Tyumen CHPP. The profits depend on the consumers' remoteness, heat input and pipeline diameter.

We have given the examples of application of these indicators for the consumers with a given heat input at a given distance. The optimum pipeline diameter, the optimum water temperature in the straight and reverse system water pipes of the consumers' heat supply system are determined.

\section{References}

1. Federalnyy zakon ob energosberezhenii i o povyshenii energeticheskoy effektivnosti io vnesenii izmeneniy $v$ otdelnye zakonodatelnye akty Rossiyskoy Federacii: feder. zakon ot 23.11.2009 № 261-FZ (Rossiyskaya gazeta, 2009)

2. A. Sokolov, Sistemnaya effektivnost otopitelnyh PGU TEC v sistemah

teploenergosnabzheniya: Dissertaciya kand. tehn. Nauk (2004) 
3. N.M. Chikisheva, Tyumeni Topical issues of construction, ecology and conservation in Western Siberia, 1, 188-192 (2014)

4. Information on http://minenergo.gov.ru/aboutminen/energostrategy

5. P. Tretyakova, Materialy mezhdunarodnoy nauchno-tehnicheskoy konferencii studentov, aspirantov, uchenyh, Chelybinsk (2013)

6. P. Tretyakova, Energosberezhenie na kurganskoy tec-2 za schet utilizacii nizkopotencialnoy teploty, Omskiy nauchnyy vestnik (2014)

7. A. Andryushchenko, Kombinirovannye sistemy energosnabzheniya (Tepoenergetika, Moscow, 1997)

8. V. Danilov, V. Slavin, Patent 2170885 Rossiyskaya Federaciya, MPK7F24D15/04, F01K17/02. Sistema teploenergosnabzheniya (2001)

9. M. Orlov, V. Sharapov, P.v Chaukin, V. Mordovin, Patent 2467257 Rossiyskaya

Federaciya, MPK7 F 24 D 3/08. Sposob teplosnabzheniya (2012)

10. V. Stenin, Patent 2239129 Rossiyskaya Federaciya, MPK7 F 24 D 3/08. Sposob teplosnabzheniya (2003)

11. V. Stenin, Patent 2266479 Rossiyskaya Federaciya, MPK7 F 24 D 3/08. Sposob teplosnabzheniya (2004)

12. A. Bogdanov. Vseros. nauch.-prakt. konf, Krasnoyarsk, 1, 20-23 (2009)

13. V. Tomilov, Y. Pugach, G. Nozdrenko, L. Pugach, Yu. Ovchinnikov, P. Shchinnikov, Patent 2163327 Rossiyskaya Federaciya, MPK7 F 24 D 3/08. Sposob centralizovannogo teplosnabzheniya (2001)

14. E. Sheremet, A. Seminenko. Primenenie teplovyh nasosov vsistemah centralizovannogo teplosnabzheniya $v$ celyah povysheniya ekonomichnosti $i$ energoefektivnosti teplovyh setey (Tepoenergetika, Moskva, 2013)

15. V. Berzan, S. Robu, M. Shyt, Problemy regionalnoy energetiki, 1, 91-94 (2011)

16. P. Tretyakova, Omskiy nauchnyy vestnik, 178-182 (2014)

17. P. Tretyakova, Pat. 2571361 Rossiyskaya Federaciya, MPK7 F 24 D 11/02. Sistema centralizovannogo teplosnabzheniya, goryachego i holodnogo vodosnabzheniya (2015) 18. A. Batukhtin, A. Kalugin, Modelirovanie sovremennyh sistem centralizovannogo teplo snabzheniya (Moscow, 2011)

19. P. Shchinnikov, Vestnik SGTU, 1, 139-149 (2004)

20. A. Batukhtin, V. Makkaveev. Primenenie optimizacionnyh modeley funkcionirovaniya sistem teplosnabzheniya dlya snizheniya sebestoimosti teplovoy energii i uvelicheniya raspolagaemoy moschnosti stancii, 1, 7-8 (2010)

21. V. Suzdaltsev, E. Takhavova, M. Shleymovich, Predstavlenie znaniy v informacionnyh sistemah, Matematicheskoe modelirovanie: uchebnoe posobie (KGTY, Kazan, 2005) 